\title{
Blue and green infrastructure proposal for an urban watershed in São Paulo to peak flow reduction
}

\author{
Proposta de Infraestrutura verde e azul para redução da vazão de pico de \\ uma bacia hidrográfica em São Paulo
}

\author{
Juliana de Alencar' \\ Daniela Rizzill \\ Lívea PereirallI \\ Ivna Gadelha Diógenes Vasconcelos ${ }^{\text {IV }}$ \\ Thais Goya Pedutov \\ Lessandro Morini Trindade $\mathrm{V}^{\mathrm{VI}}$ \\ Vanessa Constansa Becker ${ }^{\mathrm{VII}}$ \\ Murillo Henrique de Souza VIII \\ Ronaldo Gonçalves MadureiralX
}

\begin{abstract}
The critical issue of floods in Brazilian cities is a consequence of an accelerated and disordered occupation and urbanization process, which results in excessive soil waterproofing, removal of riparian vegetation, silting of rivers and streams, water pollution, among others. In the last decades, the use of conventional drainage techniques has resulted in many problems, due to the fast flow of water to downstream and the pollutant loads that flow to the watercourses. Through Green Infrastructure it is possible to promote urban rainwater storage and infiltration, reducing the probability of flooding, and allowing for the retention of pollutants and consequent improvement of water quality in urban water systems. In this study, the application of Blue-Green Infrastructure (BGI) techniques for the reduction of peak flow and improve the water quality are proposed for the Jacarezinho watershed, located in the Municipality of São Paulo. Hydrological simulations of the proposed solutions indicated a reduction of about $36 \%$ of $t$ he peak flow, which highlights the relevance of BGI. Unlike the Brazilian conventional drainage that practice the construction of monofunctional flood storage reservoirs (called in Brazil as "piscinões"), the BGI also promotes a harmonious and balanced interaction between the population and the urban landscape.
\end{abstract}

Keywords: Green and Blue Infrastructure; Urban Drainage; LID; Watershed; Hydrological control

'Polytechnic School of the São Paulo, University and Technology College of São Paulo State, SP, Brazil -

juliana.ambiental@gmail.com

"Architecture and Urbanism College of São Paulo University, SP, Brazil - daniela.rizzi@iclei.org

III Post Graduate Program in Built Environment. Federal University of Juiz de For a, MG, Brazil - livea.rocha@gmail.com

Iv Master student in city sciences, Fortaleza University, CE, Brazil - ivnagadelha@gmail.com

v ABC Federal University and Technology College of São Paulo State, SP, Brazil - Thais.goya@outlook.com

VI Institute of Hydraulic Research / Federal University of Rio Grande do Sul, RS, Brazil - lessandromt@gmail.com

VII Leonardo DaVinci University Center, BA, Brazil - vanseth@hotmail.com

VIII Nove de Julho University and Technology College of São Paulo State, SP, Brazil - murillo_henri@hotmail.com

${ }^{1 x}$ Environmental Management Department of the São José dos Campos Municipality, SP, Brazil - ronaldo.madureira@sjc.sp.gov.br 


\section{Resumo}

A questão crítica das inundações nas cidades brasileiras é consequência de um processo acelerado e desordenado de urbanização, que resultou em impermeabilização excessiva do solo, remoção de mata ciliar, assoreamento de rios e córregos, poluição da água, entre outros. Nas últimas décadas, o uso de técnicas convencionais de drenagem resultou em muitos problemas, devido ao rápido escoamento das águas para jusante e às cargas de poluentes que afluem para os cursos de água. Através da Infraestrutura Verde é possível promover o armazenamento e a infiltração de águas pluviais urbanas, reduzindo a probabilidade de inundações e permitindo a retenção de poluentes e consequente melhoria da qualidade da água em sistemas urbanos. Neste estudo, a aplicação das técnicas de Infraestrutura Verde-Azul (IVA) para a redução da vazão de pico e melhoria da qualidade da água são propostas para a bacia hidrográfica do Jacarezinho, localizada no Município de São Paulo. Simulações hidrológicas das soluções propostas indicaram uma redução de cerca de $36 \%$ da vazão de pico, o que evidencia a relevância da IVA. Ao contrário da drenagem convencional brasileira que pratica a construção de reservatórios de detenção monofuncionais (chamados no Brasil de piscinões), a IVA também promove uma interação harmoniosa e equilibrada entre a população e a paisagem urbana.

Palavras-chave: Infraestrutura Verde e Azul; Drenagem Urbana; LID; Bacia Hidrográfica; Controle Hidrológico 


\section{Introduction}

The urbanization process results in changes in the rates of flow and infiltration, as well as in the speed of the flow, which in turn results in changes in the peak flows of the urbanized watersheds. The conventional drainage system was created based on the premise of rapid flow in order to ensure that there was no contact of the population with potential pathogens present in it, which is known as the sanitary drainage system. The reflection of the adoption of this system is the overload of downstream systems and the degradation of water quality due to the absence of processes that generate the pollutants retention. In addition, these traditional systems prevent natural processes that sustain life from occurring, resulting in great environmental damage (Findlay \& Taylor, 2006). In response to conventional systems, techniques that work with both quantitative and qualitative control at the source of runoff, which is one of the main premises of the Blue-Green Infrastructure (BGI).

Benedict and McMahon (2006), based on the concepts of landscape ecology coined by Forman (1995), were the first authors to highlight the important role of natural areas in the maintenance of water resources and the quality of life of the population. Initially, the authors used the term green infrastructure, which was used with the focus on preservation, conservation, and maintenance of natural systems, and was later adapted to meet the needs of cities. More recently with an understanding of the importance of waters in this process, the term has been adapted for Blue-Green Infrastructure. Nowadays, the BGI integrates ecosystem services, provided by natural areas, and the hard infrastructure with the urban needs. Focusing on rainwater, $\mathrm{GBI}$ can count on several devices to control the flow, ending the quantitative and qualitative improvement (Cormier \& Pellegrino, 2008). In addition, the BGl seeks to promote the formation of an interconnected network of green areas, not only through vegetation, but also of the atmosphere, water, and soil, resulting in several services for the population (De Oliveira et al., 2012).

This concept goes beyond the common sense of understanding landscape design as an exclusively artistic and aesthetic discipline, because it actually promotes 
the planning of the urban landscape in order to integrate existing green areas and landscape element into a more comprehensive Blue-Green Network within an anthropized environment. It consists of incorporating control devices at the source in a network of green areas and open spaces within the urban watershed, promoting new uses, new dynamics and new behaviors towards these areas, which are fundamental for a socio-environmental reframing of the territory. While conventional drainage systems have as a principle the rapid transfer of water downstreams, BGI proposes to intervene in the territory in a way that increases its social and ecological value, while the adopted measures also promote the reduction of peak flow. Source control devices, also known as compensatory measures, are called Low Impact Development (LID) devices, which use or mimic natural processes that result in the infiltration, evapotranspiration or use of stormwater in order to protect water quality and aid in the management of quantity. Best Management Practices (BMPs) are more linked to non-structural measures, i.e. management techniques or measures and practices aimed at improving rainwater quality (Tomaz, 2008).

In the USA, LID techniques have been employed to make urban drainage systems more similar to natural systems. There are several LID manuals, especially in Portland (Oregon) and Seattle (Washington) that validate reduction in runoff through low impact techniques. The City of Portland achieved 35\% improvement in the absorption of precipitated water by implementing green roofing, infiltration trenches, grass banding, porous paving and adopting an environmental education program. According to Atkinson (2015), the Tabor River Program involves the installation of more than 500 "green streets", along with tree planting, private property reform, and replacement piping to the sewer in the worst conditions, using facilities with vegetation to deal with the stormwater runoff on site, distributed throughout the city of Portland. The combination of gray and green infrastructure in the Tabor Program for Rio saved about $\$ 50$ million compared to a gray solution. By adopting similar measures in the city of Portland on its SEA Street pilot project, Seatlle achieved savings of about 25 percent on expenditures traditionally applied to pollution control, asphalt maintenance, and sidewalk spending, and a percentage of precipitated water 
retention of $37 \%$, due to its focus on the use of green areas for the absorption of water in grassy strips. In Scotland, the adoption of the sustainable drainage system (SUDS) has avoided road accidents, the rapid absorption of rainwater prevents the formation of ice on the highways (Poleto, 2011).

Among a wide range of LID devices that can be applied in the urban environment, there are those associated to bioretention, which allow a slowing of surface runoff and consequent reduction of flood peaks, and those associated to infiltration, which promote the reduction of the drained volume and allow for the recharge of the subterranean waters, which also contribute to the reduction of flow peaks, diminishing the probability of flooding downstreams. LID devices, in addition to promote a spatial rearrangement of water flows within a given watershed, also enable multiple uses in open spaces throughout the urban territory. Resulting benefits are the encouragement of citizen contact with the water element, the provision of new leisure and recreation options, the summing up of urban areas with ecological diversity, and the improvement of water quality and flood risk control.

A BGI approach is proposed for the Jacarezinho watershed, describe bellow, by redesigning the landscape as a multifunctional system capable of promoting the interaction between local society and the natural and built environment, and of reorganizing ecological, spatial and social relations in the scale of the watershed.

\section{Study area}

The object of analysis of the present study was the Jacarezinho watershed. A tributary of the Jaguaré River, the Jacarezinho's stream is located in the West Zone of the city of São Paulo, being the main access to its Raposo Tavares Highway, as is possible to see in Figure 1. The Jacarezinho watershed has an area of approximately 0,78 square miles and a rich water network of 4,16319 miles long that preserves about $70 \%$ of its waterways in open channels, or only $30 \%$ of the others in underground galleries. 
Figure 1 - Jacarezinho watershed

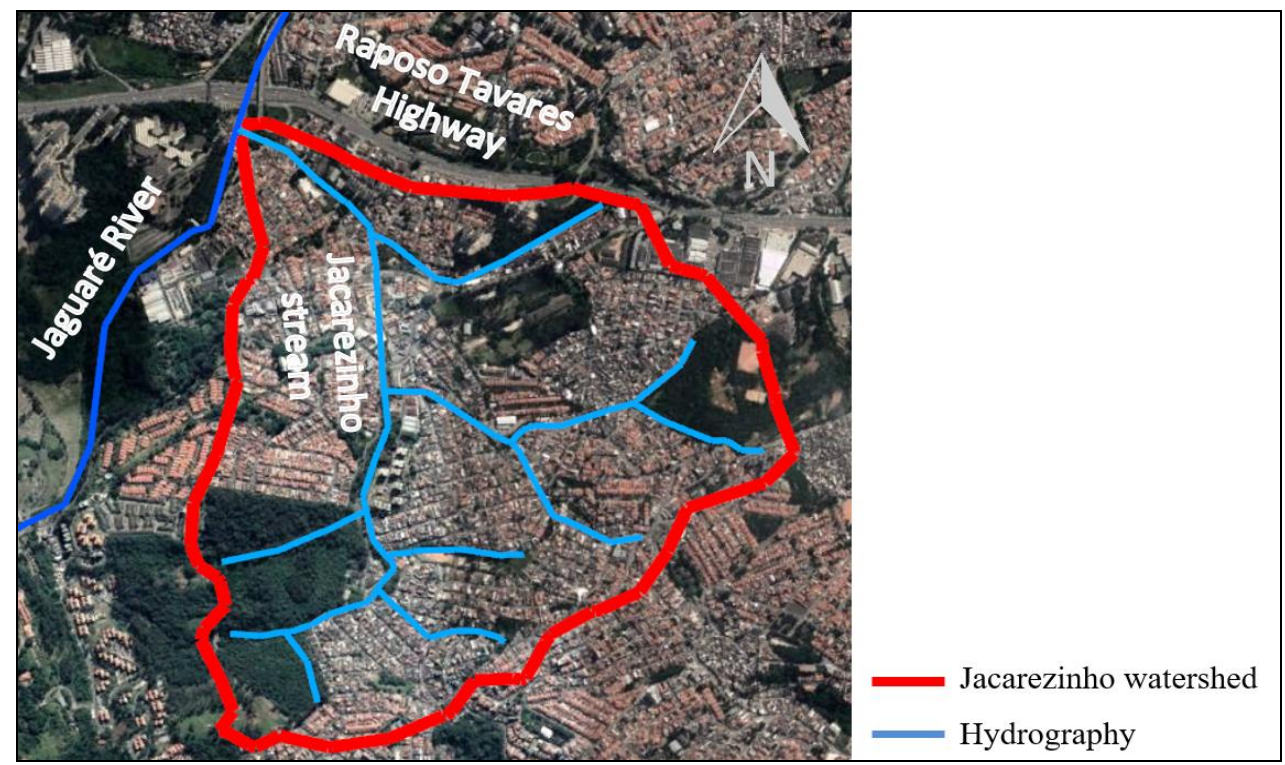

Source: By the Authors (From Google Earth, 2018)

The watershed has several problems related to drainage and presents several points of overflow because of the deficiencies in the micro drainage and the floods present in its mouth, next to the Jaguaré River. In addition, there are sanitary problems related to the lack of sewage treatment and to the inefficient solid waste collection system, as shown in Figure 2, below.

Figure 2 - Sanitary problems found in the Jacarezinho watershed
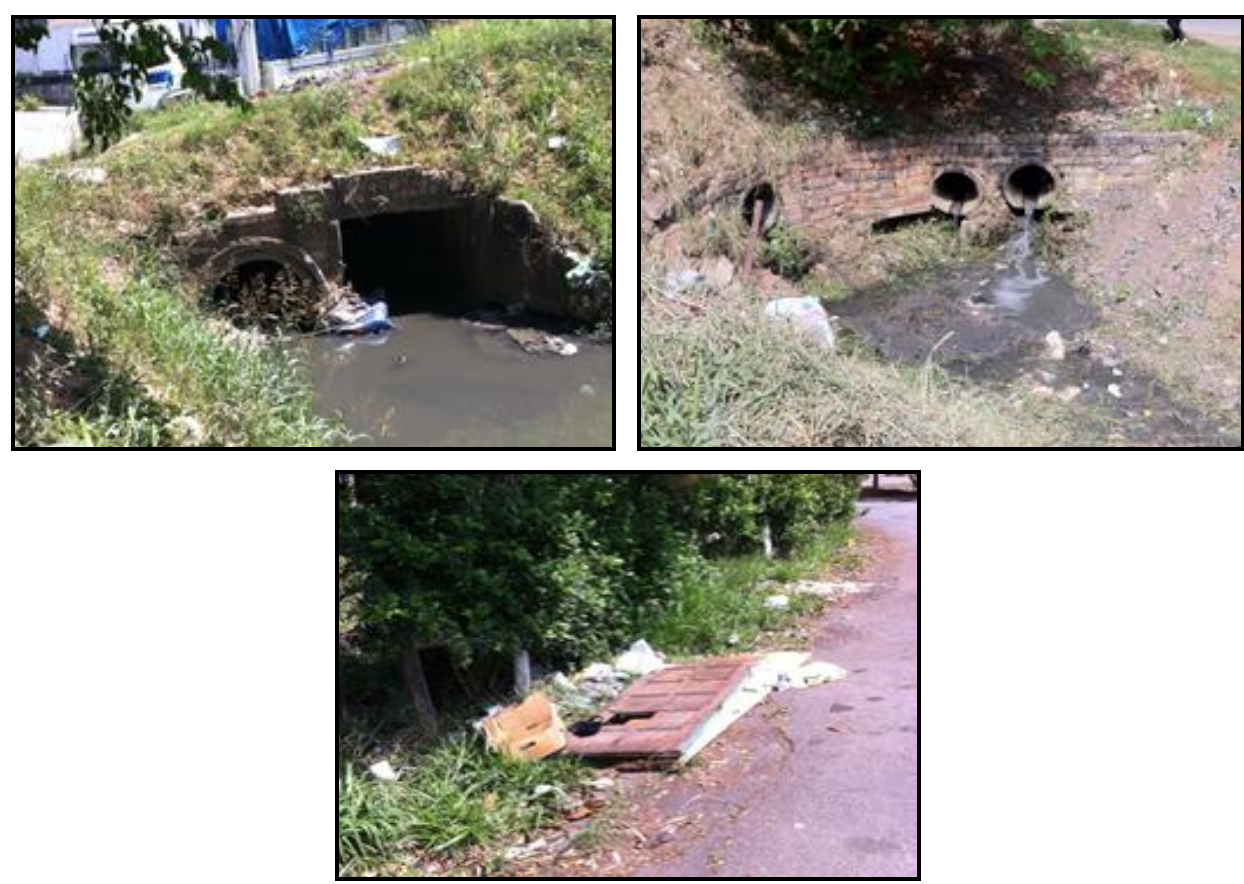

Source: Author's photo 
The lack of basic sanitation services results in problematic health conditions for local people, that suffering from water-related infectious diseases. Such scenario requires the search for integrated solutions that address health and environmental issues. In this study it was proposed the adoption of several Green and Blue Infrastructure techniques in a system of open green spaces in order to solve the problems related to drainage and pollution in the watershed, as will be described in more detail below.

The Jacarezinho watershed is located in the subtropical zone, with hot and rainy summers and cold and dry winters. The analysis of mean precipitation in the basin, obtained from the São Paulo Flood Alert System (SAISP), reveals that the maximum precipitation in the basin is recorded between November and February and the minimum between May and July. Due to the excess of impermeable areas and the natural characteristics of precipitation concentration in summer, the watershed suffers from the flooding of some canals and flooding of streets due to saturation of the drainage system (a phenomenon that is further exacerbated by clogging drainage due to poor management of solid waste), requiring specific studies for solutions to these vulnerabilities.

\section{Methodology}

To verify the performance of the BGI adoption in the Jacarezinho watershed, the following methodology was performed: 1) Characterization of the Jacarezinho watershed to provide inputs to the hydrologic modeling (soil use and occupation, hydrological, social and geomorphological characteristics); 2) Determination of typologies to LID devices adoption in the streets of the watershed; and 3) Calculation of peak flow for the each scenarios considered. The flow chart of the methodology is shown in Figure 3. 
Figure 3 - Flow chart of the methodology

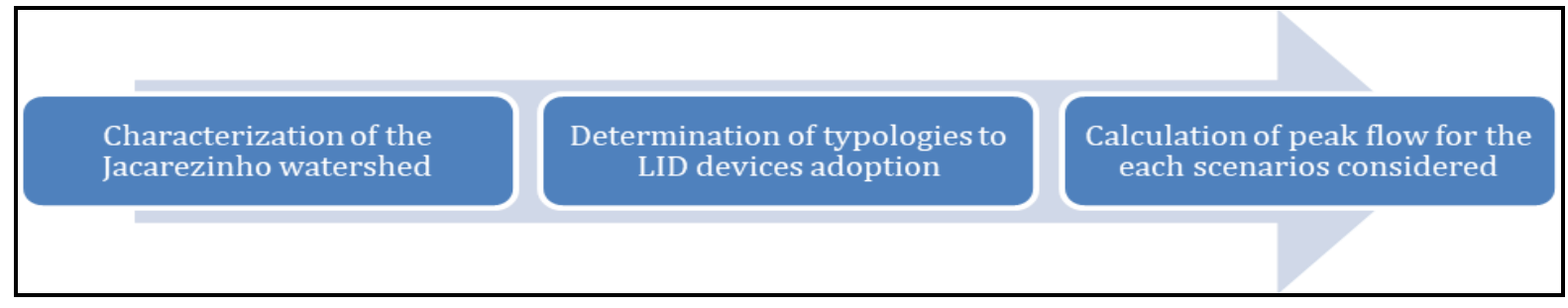

Source: By the Authors

In order to characterize the watershed, we used information from previous studies within the scope of the Jaguare Project, carried out by the Hydraulic Center Foundation of the São Paulo University, visits to the study area, as well as consultation with the registers of the São Paulo Municipality and of the Brazilian Geological Survey.

Next, the selection of LID devices more suitable for application in the context of the watershed was carried out. The use of LID devices requires that the natural hydrology of the studied watershed be identified and characterized for the understanding of the water distribution pattern, the connectivity between the streams, and the delimitation of the catchment areas and the flow paths (UACDC, 2010). In order to reduce the peak flow within the watershed, the following techniques were considered: permeable walking lanes; bioretention band, and permeable passage.

Site visits and analyses of cartographic material were carried out to support the spatial rearrangement of twenty roads of the Jacarezinho watershed, whose width and slope have shown to be suitable for the application of LID devices, as shown in Figure 4. These streets were classified according to the following widths: streets up to 8 meters wide, streets from 8,01 meters to 10 meters wide, and streets from 10.01 meters to 12 meters wide. The total width of the street was considered, i.e. from lot to lot, considering both the carriage bed and the sidewalks.

The classification of the streets according to three width ranges enabled a pragmatic redesign pattern in which space for the installation of LID devices was suggested, as shown in Figure 5. 
Figure 4 - Streets selected for LID devices adoption

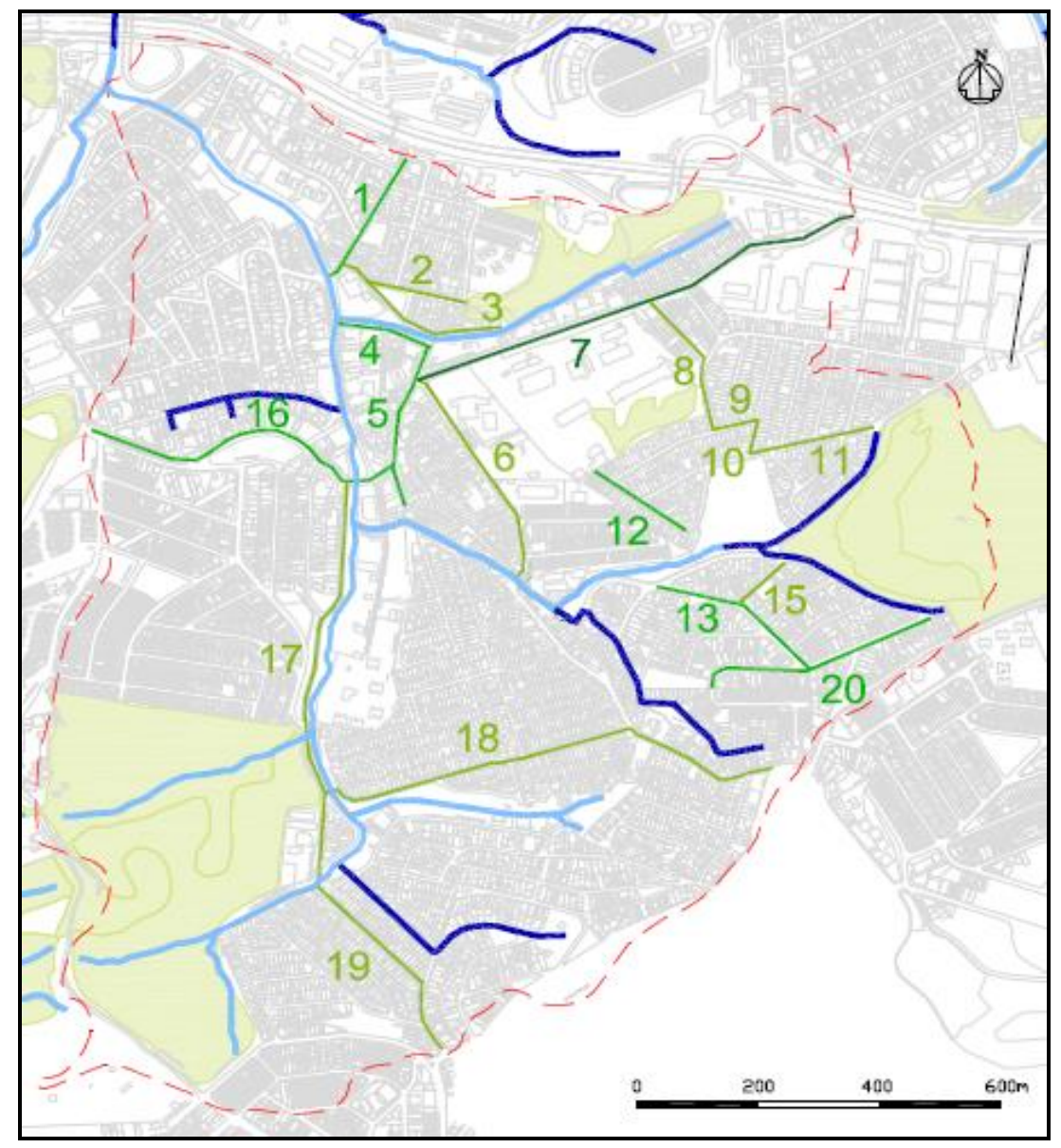

-- Jacarezinho watershed

- Open Channels

- Close Channels

Typology 1

- Typology 2

- Typology 2
Typology 3

Source: By the Authors

Figure 5 - Typologies of streets with LID devices adopted on the streets of the Jacarezinho watershed

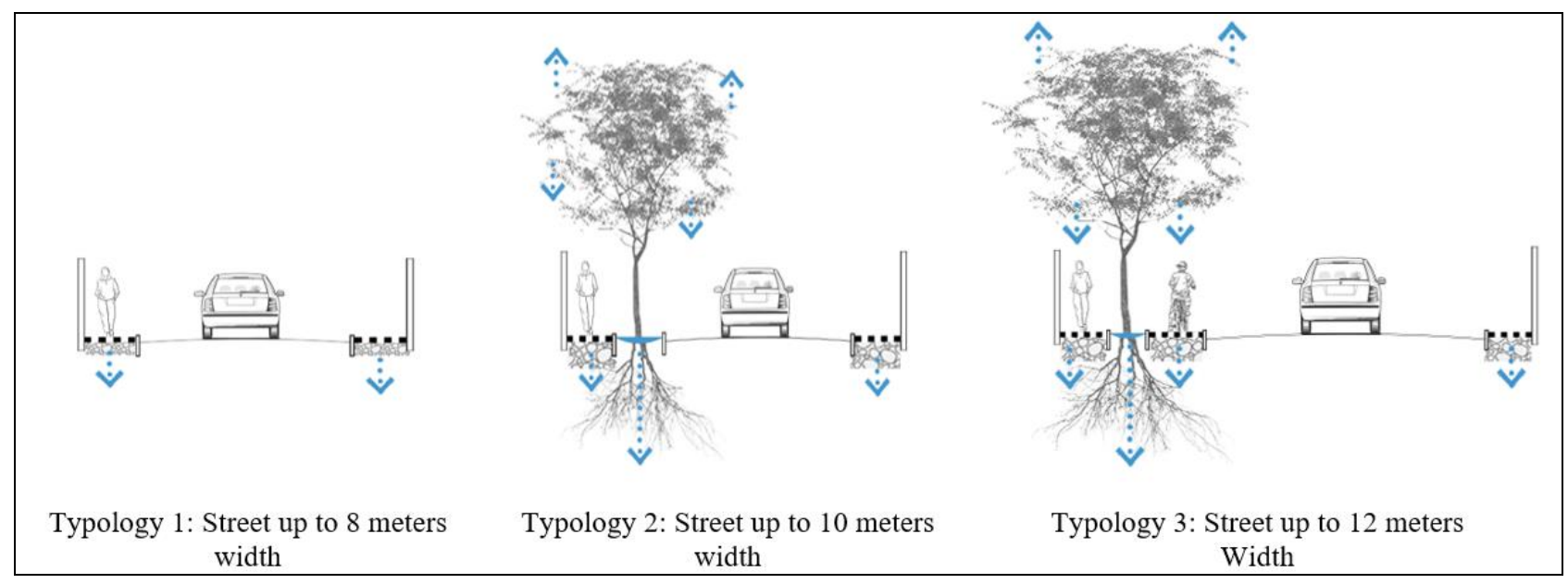

Source: By the Authors 
The intervention typology 1 related to the narrowest streets, i.e. those that would present greater difficulty for the application of bioretention devices beforehand. These narrow roads are often those that carry lowest vehicle traffic. Light traffic and slopes of less than $5 \%$ of declivity are suitable to have their asphalt replaced for porous asphaltic pavements, known in Brazil as CPA. However, if the streets are narrow and of medium or high traffic, a permeable pavement is not advisable. Permeable pavements reduce surface runoff, delaying the arrival of the water at the watershed's lowest points, and at a local scale, they hinder the fast percolation of water in the subsurface layer, what reduces erosion risks. In addition to its application being feasible in sidewalks, permeable pavement is also adequate to be used in parking lots with gentle declivity. In this typology, permeable pavement was suggested only in the sidewalks in order to promote peak flow reduction in the watershed.

Typology 2 refers to streets with a width range between 8 and 10 meters, for which a higher application rate of LID devices was predicted: permeable pavement in the footpaths, and stormwater medians alongside the street, between the asphalted lanes and the sidewalks. The stormwater median is a bioretention linear cel with the function to receive runoff from the surrounding impervious areas. A composite engineered soil (soil, organic matter, sand and stones) with high porosity is suggested for this device, allowing it to function like a sponge. Vegetation should be chosen according to criteria of species adaptability to local environmental conditions. The vegetation should be sufficiently robust to withstand periods of drought, as well as being able to withstand high water volumes. The removal of pollutants from the collected runoff shall occur through the action of microorganisms associated to the rhizosphere of the plants. Likewise the permeable pavement, the stormwater median increase infiltration rates and promotes a flush delay, but other than that, whilst promoting a temporary storage of stormwater it also allows for desirable biological processes which improve the environmental situation of the watershed, such as evaporation when water is stored, evapotranspiration when these devices host trees, air filtration, non-point source phytobiological treatment, and groundwater recharge in the infiltrating versions of the device. In addition, the stormwater median increase 
air humidity, what encourages the maintenance of urban habitats by increasing the presence of green in the street network and providing green connectivity.

Typology 3 is the most generous regarding the LID applicability. It is suggested that in addition to permeable pavement on the sidewalks and to the stormwater median along one side of the road, drainage pavement also be applied to the cycleway, alongside the stormwater median. This typology presents all the benefits expected from Typology 2 , with the advantage that the LID area is wider, increasing the environmental benefits.

The retention capabilities of the devices selected were obtained using the methodology proposed by Pellegrino and Moura (2017). The calculations indicate the total retention capacities per $\mathrm{m}^{2}$ of LID device, as shown in Table 1.

Table 1 - Retention capacity of the proposed typologies

\section{Typology 1}

\begin{tabular}{l|l}
\hline 2 permeable walking lanes & 0.28 \\
\hline Capacity total $\mathrm{m}^{3} / \mathrm{m}^{2}$ & 0.28 \\
\hline
\end{tabular}

Typology 2

\begin{tabular}{l|l}
\hline 2 permeable walking lanes & 0.28 \\
\hline 1 bioretention band & 0.71 \\
\hline Capacity total $\mathrm{m}^{3} / \mathrm{m}^{2}$ & 0.99 \\
\hline
\end{tabular}

Typology 3

\begin{tabular}{l|l}
\hline 2 permeable walking lanes & 0.28 \\
\hline 1 bioretention band & 0.71 \\
\hline 1 permeable passage way & 0.14 \\
\hline Capacity total $\mathrm{m}^{3} / \mathrm{m}^{2}$ & 1.13 \\
\hline
\end{tabular}

Source: By the Authors (From Pellegrino and Moura, 2017) 
To assist in the BGI application, was defined areas along the watercourses of Jacarezinho watershed for a Linear Park implantation. In these areas, was provided the creation of detention zones creation to reduce the peak flow in the channel. Because it has larger portions of the territory than squares and roadbeds, with mainly generous areas in the extension sections of the linear course, the linear park can perform several hydraulic functions: detention, retention, conduction and retention. Based on the lower slope topography along the water courses and the individual analysis of the existing lots in the direct environment, strategic areas were identified for the formation of Linear Parks. After identifying these areas, It was possible to remodel the land in order to prepare it for the installation of a series of devices that contribute to the damping of the surface runoff. Working as an in-line reservoir, from the introduction of flow restrictions along the existing channel. For this, it is necessary that the land adjacent to the channel is altered in some stretches to retain larger volumes of water in rainy events.

In specific sections of the Linear Park, areas with capacity to install sedimentation devices have been defined, in order to guarantee the effectiveness of the in-line reservoir by stopping the sediments and any suspended solids before they reach the reservoir and cause obstruction.

An area for installation of Rain Gardens was chosen according to the functionality and efficiency of rainwater absorption, prioritizing the creation of gardens that require little maintenance, and have high tolerance for the elements in the elements, the drought and the stress of heavy rains such as pollutant loads and excess nutrients. The Gardens are designed for this purpose according to each case, being "a minimum dimensioning criterion, $5 \%$ of the impermeable surface area" (MELO et al., 2014).

According to FCTH, water captured by the Rainforest can be infiltrated and recharged to the existing aquifer system, or even discharged into the drain micro drainage system, especially at events in which rainfall exceeds what is expected. It is indicated to be implanted in wide streets and of low traffic, wide sidewalks, patio, 
parking lots and in the residential, commercial or public lots. The area that should be reserved for the direction of rainwater must be less than 1 ha, that is, 10,000 m2.

The soil infiltration capacity must also be analyzed, since it influences the performance of the device. In the case of Rain Gardens, the site soil must have an infiltration capacity between 7 and $200 \mathrm{~mm} / \mathrm{h}$. Another factor to consider is the level of the water table, and the maximum level should be up to $1 \mathrm{~m}$ below the bottom of the device. If the level of the water table is high (more than $1 \mathrm{~m}$ from the bottom), the implantation of the Rainforest will only be viable if its bottom is waterproofed.

Lastly, the rational method was adopted to establish a relationship between rainfall and surface runoff. It was first adopted in the United States in the year 1889 by Emil Kuichling. Equation (1) is applied to calculate the peak flow of a watershed, considering its study section (TOMAZ, 2013).

$$
Q=\frac{C . I . A}{360}
$$

Being: $\mathrm{Q}=$ peak flow $\left(\mathrm{m}^{3} / \mathrm{s}\right) ; \mathrm{C}=$ surface variation of flow coefficient 0 to $1 ; \mathrm{I}=$ average rainfall ( $\mathrm{mm} / \mathrm{h}) ; \mathrm{A}=$ watershed area (ha).

Four scenarios were considered in modeling: In scenario 1 the pre-development condition was simulated, where it was adopted that $100 \%$ of this one had native vegetation; In scenario 2 , the current land use and occupation situation of the Jacarezinho watershed was considered; In scenario 3, it was considered the critical scenario with the loss of the existing green areas; Finally, scenario 4 considered the propositional scenario, based on the adoption of several Green and Blue Infrastructure techniques.

\section{Results and discussion}

The characterization of the land use and occupation of in the watershed revealed that it has about $26 \%$ of open spaces and green areas, which represents a significant 
portion, considered the average rate of the São Paulo city. Figure 6 below shows the map obtained with the characterization of land use and occupation in the Jacarezinho watershed and Table 2 the distribution of land use and occupation typologies as well as the $\mathrm{C}$ used in hydrological modeling for each typology.

Figure 6 - Map of Land use and occupation in the Jacarezinho watershed

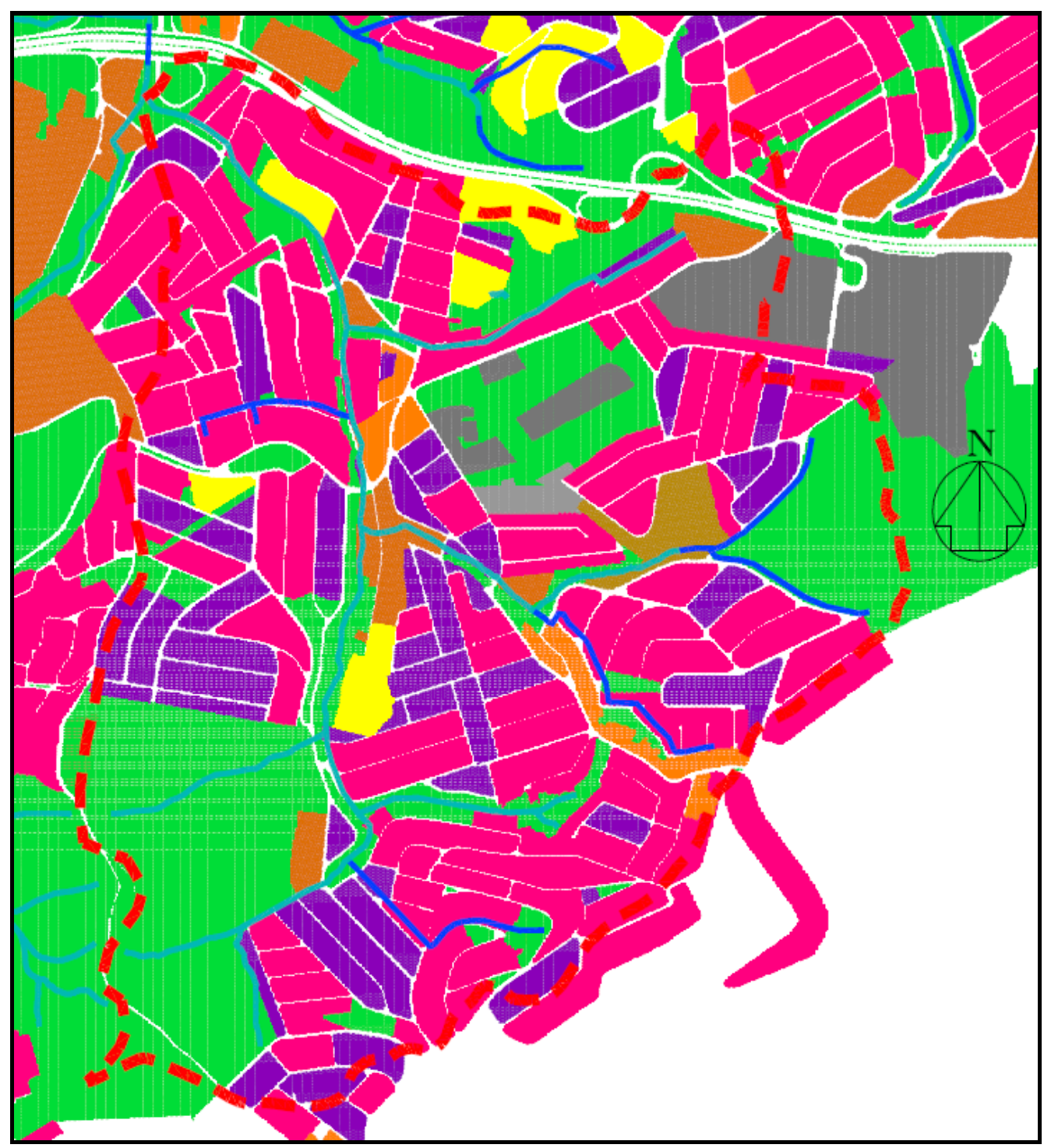

U Urban green spaces Urban green spaces

$\square$ Edifices

- Houses- Continuous

- Houses- Discontinuous

$\square$ Slums

Trade and Services - Continuous

- Trade and Services - Discontinuous

- Industrial - Continuous

- Industrial - Discontinuous

Source: By the Authors (From Silva, 2017) 
Table 2 -Distribution of the Land use and occupation in the Jacarezinho watershed and the $\mathrm{C}$ coefficient adopted

\begin{tabular}{l|c|c|c}
\hline \multicolumn{1}{c|}{ Land use and occupation } & $\mathrm{km}^{2}$ & $\%$ & $\mathrm{C}$ \\
\hline Urban green spaces Urban green spaces & 0.52 & 26.33 & 0.77 \\
\hline Edifices & 0.08 & 3.83 & 0.85 \\
\hline Slums & 0.04 & 1.86 & 0.98 \\
\hline Houses- Continuous & 0.39 & 19.74 & 0.98 \\
\hline Houses- Discontinuous & 0.69 & 34.72 & 0.85 \\
\hline Trade and Services - Continuous & 0.04 & 1.86 & 0.95 \\
\hline Trade and Services - Discontinuous & 0.07 & 3.75 & 0.89 \\
\hline Industrial - Continuous & 0.01 & 0.73 & 0.93 \\
\hline Industrial - Discontinuous & 0.14 & 7.16 & 0.83 \\
\hline Total & 1.98 & 100 & 0.860 \\
\hline
\end{tabular}

Source: By the Authors (From Silva, 2017)

According to the geological map of the CPRM (Geological Survey of Brazil Aquifers) the Jacarezinho watershed is located in the geological unit call intrusive Granitoids, presenting a shallow layer of organic clay soil followed by altered magmatic rocks, which guarantees these units low capacity of underground recharge, information considered in the definition of the coefficients $C$ adopted.

Knowing the characteristics of land use and occupation in the watershed, the study to define the potential areas for application of BGl techniques was started, which resulted in the proposition of a linear parks network, presented in the map of Figure 7. The map shows the most suitable open areas for implantation of BGI techniques, such areas were identified in the visits to the watershed. For the selection of these areas, the following factors were considered: topography, the dominance of the area (public or private) and continuity of open spaces in the urban space.

Among the selected streets for the application of LID devices, many of them had very narrow or even nonexistent sidewalks, i.e. out of the urban parameters defined 
by the Municipal Law 15.733/2013, which demands a minimum width of $1.2 \mathrm{~m}$ for the passage of pedestrians on sidewalks. In the street rehabilitation proposal, a narrowing of the existing carriageway bed is suggested, in order to prioritize the access of pedestrians and the integration of adaptive measures of BGI.

It is imperative that there be legal instruments and technical training so that adequate treatment can be given to open spaces in order to protect these areas. It is recommended that there be greater integration among government departments so that sectoral aspects do not weigh on the public interest, implying favoring of irregularity and inefficiency of inspection. The benefits arising from the presence of green spaces in urban areas are numerous, so these areas must be protected.

Figure 7 - Intervention areas in the Jacarezinho watershed

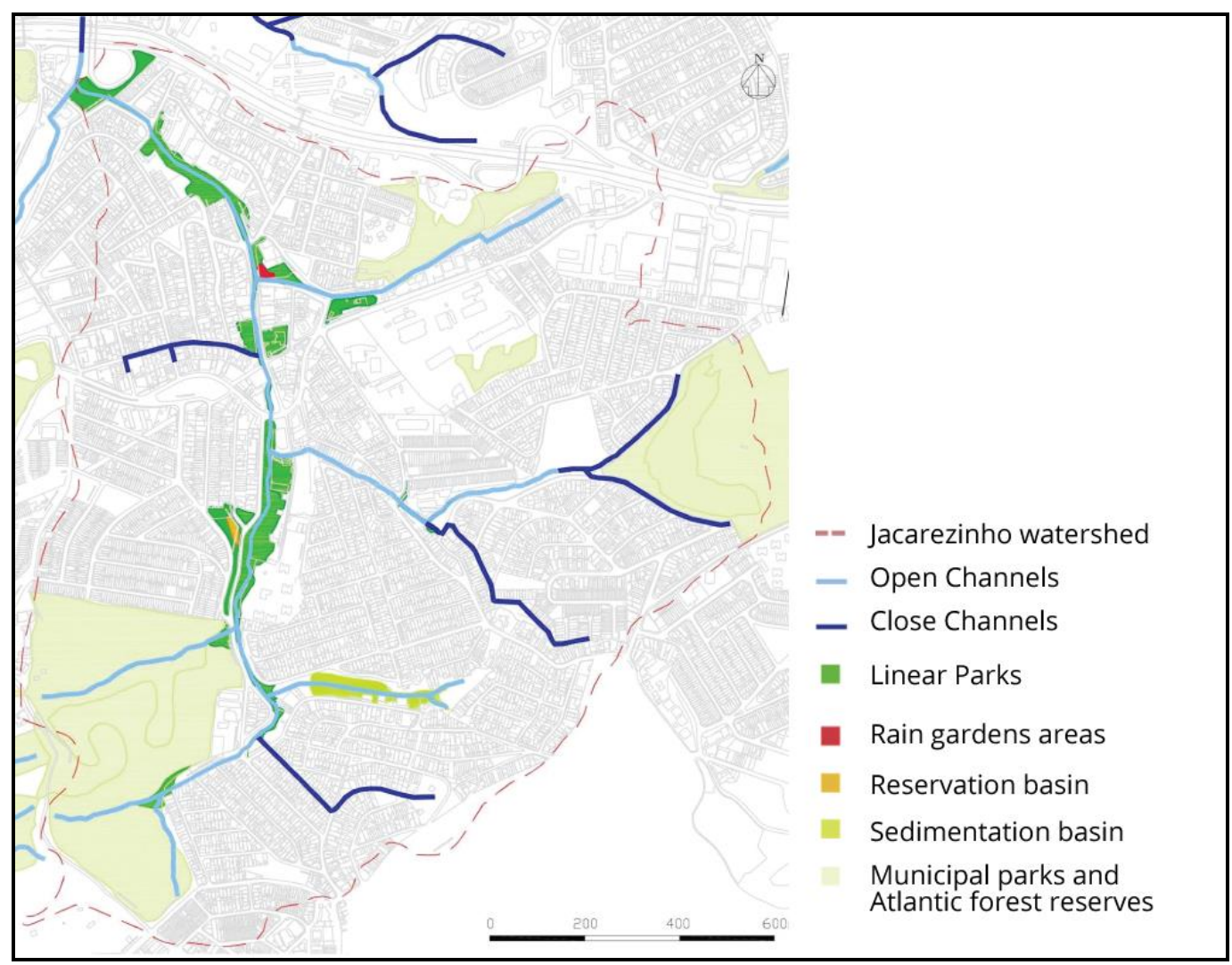

Source: By the Authors

Based on these first results obtained (hydrological, topographical, geomorphological and areas for the BGI), it was possible to realize the hydrological modeling. In scenario 1 the pre-development condition was simulated, where it was 
adopted that $100 \%$ of this one had native vegetation, which resulted in a $\mathrm{C}$ of 0.3 ; In scenario 2, the current land use and occupation situation of the Jacarezinho watershed (Table 2) was considered, resulting in a C of 0.86 ; In scenario 3, it was considered the critical scenario with the loss of the existing green areas, which resulted in a C of 0.95; Finally, scenario 4 considered the propositional scenario, based on the adoption of several Green and Blue Infrastructure techniques.

The set of graphs shown in Figure 8 below shows the evolution of the peak flow for the simulated scenarios. It is possible to observe the increment brought by the process of urban occupation in the Jacarezinho watershed, with a increase in the peak flow from $24.35 \mathrm{~m}^{3} / \mathrm{s}$ to $69.77 \mathrm{~m}^{3} / \mathrm{h}$ and increasing still to $77.12 \mathrm{~m}^{3} / \mathrm{s}$ in that scenario where there is the conversion of the green areas of the watershed to urban use. In addition to the increase of the peak flow, it is also observed the advance of the peak flow due to the waterproofing. The adoption of the Green and Blue Infrastructure techniques proposed in this study causes a significant reduction in the peak flow of the Jacarezinho watershed with $44.65 \mathrm{~m}^{3} / \mathrm{s}$, representing an expressive gain in its hydrological control.

Figure 8 - Peak flow evolution in simulated scenarios for the Jacarezinho watershed

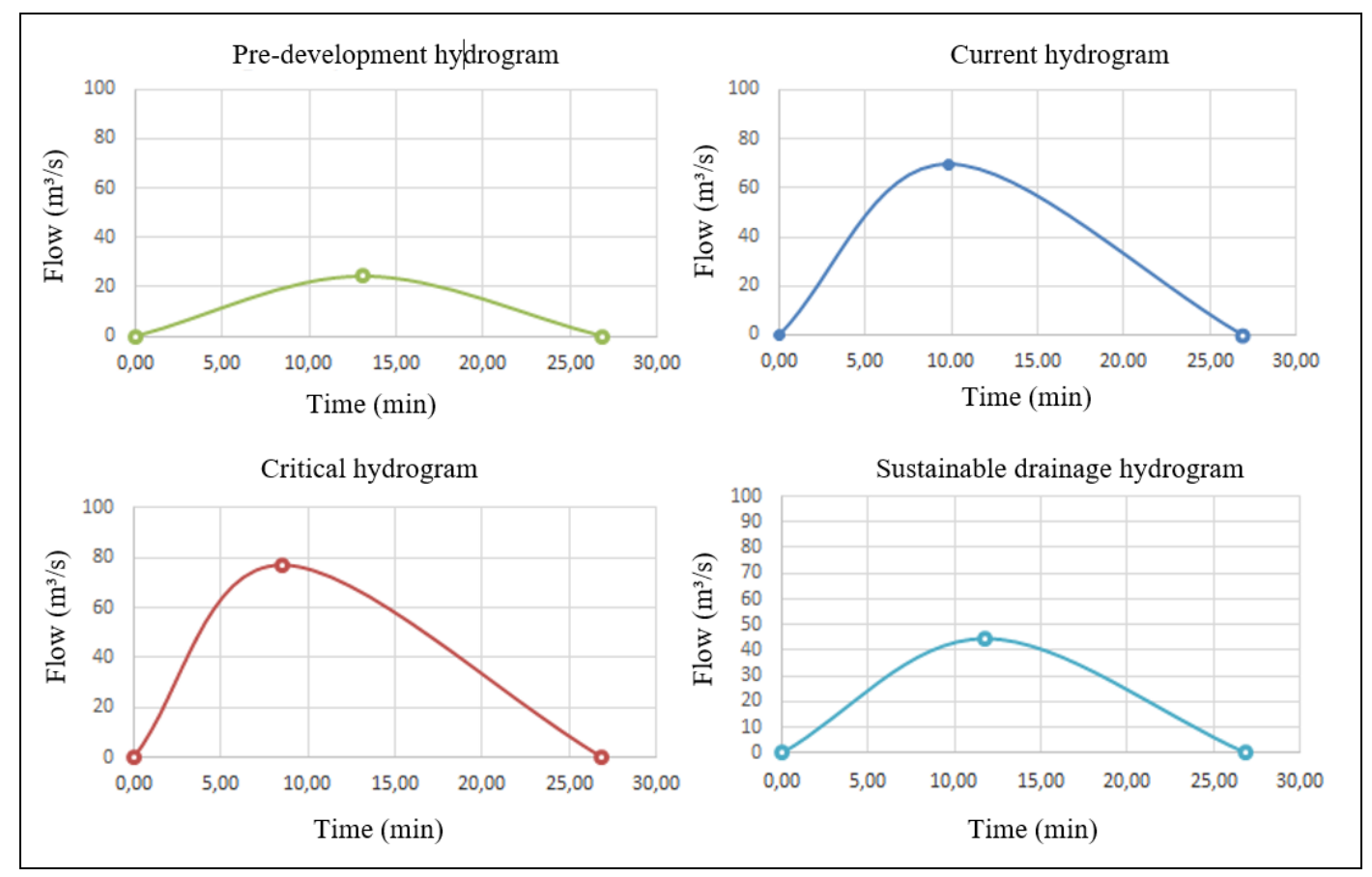

Source: By the Authors 
The Federal Constitution itself guarantees everyone the right to a balanced environment, of common use and adequate to the quality of life of the population. For this, the Public Power, in partnership with the community, must defend, preserve and even recover the natural environment, even if it is permeated by the urban environment, through non-structural measures of an institutional nature, legal and administrative. It is important to encourage actions aimed at mitigating the problems of floods and water pollution. This right "must be the object of public policies" in different segments, in order to provide a safe and dignified environment for the wellbeing of all.

The City Statute establishes "the basis for a democratic model of a city and the rules for the use of property for the benefit of the collective good, security and wellbeing of citizens." In its guidelines, it clarifies the guarantee of the right to sustainable cities with access to urban land, housing, sanitation, infrastructure and transportation, among others, for present and future generations; democratic management with the participation of the population in plans and projects aimed at urban development; and cooperation between government, private initiative and others, in search of a process of urbanization that serves social interests (BRAZIL, 2001).

Green taxes are tributary mechanisms aimed at protecting the environment, serving as a guide for political and economic decision-making in line with ecologically sound practices. The use of these as an instrument of environmental protection, seeks in prevention ways to avoid further damage to the environment.

Since 2011, law projects aimed at implementing a Green Tribute in São Paulo have been going through the legislative house. Examples are draft Law 39/2011 and PL 568/2015 in accordance with Law 16.050 / 2014, which establishes an incentive and discount program, called IPTU VERDE within the scope of the Municipality of São Paulo. This solution is adopted by several countries and by some Brazilian municipalities, as well as in much of the State of São Paulo.

An important example to be mentioned is the Municipal Law 13.276 / 2002, which makes it compulsory to build reservoirs for the water collected by roofs and floors in batches, whether or not built, with a waterproofed area of over $500 \mathrm{~m}^{2}$. For a 
land with a waterproofed area of $500 \mathrm{~m} 2$, for example, the capacity of the reservoir will be $4.5 \mathrm{~m}^{3}$. Actions such as this help to transfer to the owner the responsibility for controlling the increase in the peak flow brought with the implementation of an enterprise.

It is necessary to stimulate sustainable actions and support the adoption of constructive and low-impact techniques aimed at the rational use of water, energy, waste management, and increasing soil permeability. In order to preserve existing permeable areas and convert impermeable areas into permeable, it is important that the Subprefecture privilege the proposition of Linear Parks and Greenways, as well as the installation of LID devices in public areas such as road beds, roundabouts and squares. Those Linear Parks that are already demarcated in the Strategic Master Plan of the Municipality of São Paulo, should have even more generous perimeters by incorporating the surrounding areas that can be integrated into the Park, in order to boost its "anti-flood" function and increase the direct benefits these areas bring to the local population.

\section{Conclusions}

The Jacarezinho watershed proved to be an interesting object of study because it presents many challenges of sanitation, drainage, and urbanity due to its different patterns of urban occupation and the varied spatial and social realities that it presents. In this study, it was possible to verify the importance of the adoption of Green and Blue Infrastructure techniques for the watershed in order to reduce the peak flow. The proposed approach is valid also for other Brazilian urbanized river watersheds, since in addition to opposing the traditional approach of adopting conventional techniques in urban areas (such as detention reservoirs, which are known to present several sanitarians and social problems), also opens a wide range of urban and landscape benefits that in addition to promoting improvement in the quality of life of the inhabitants of the watershed, provides their environmental recovery. 
It is recommended to search for unconventional projects and improvements in green areas in order to connect Conservation Units, Linear Parks, green corridors, public green spaces such as squares and free areas such as parking lots, in order to provide flood and diffuse pollution control in the watershed. Besides promoting greater integration of man and nature. It is an integrative approach to the urban landscape in which a new generation of BGI is proposed not only with a focus on their technical functioning related to volume data but also in order to aggregate other values such as the increase of areas of recreation and contemplation, increased urban mobility, recharge of aquifers, microclimatic regulation, among others.

The lack of a full view, that we are all part of a single integrated system, separates nature from human actions as if human activity did not depend on and interfere with the environment. For such an approach to be successful, it is important that constant and efficient environmental monitoring, continuous actions for the environmental education of the population and the effectiveness action of the to the municipality in the regulation plans of land use and occupation.

Intervening in an anthropized environment, even in order to improve HDI (Human Development Index), must involve the local population in co-authoring the actions, in order to foster a sense of belonging and identification with the urban landscape. It is important to seek sustainable solutions based on the most modern urban drainage and sanitation premises, through an integrated and multidisciplinary analysis of the watershed and its surroundings.

\section{References}

ATKINSON, W. Planned sustainability: the greening of water infrastructure. 2015. Available at: https://www.waterworld.com/ articles/print/volume-31/issue4/features/planned-sustainability-the-greening-of-water-infrastructure.html. Accessed on: Oct, 2018.

BENEDICT, M.A ;; MCMAHON, E. T. Green Infrastructure - Linking Landscapes and Communities. Island Press, Washington, 2006. 
BOCHI, T. C. Urban river corridors: environmental perception and urban design. 2013. 218f. Dissertation (Master in Urban and Regional Planning). Faculty of Architecture and Urbanism, Postgraduate Course in Urban and Regional Planning, Federal University of Rio Grande do Sul, Porto Alegre, 2013.

BRAZIL. Constitution of the Federative Republic of Brazil. Brasília, DF: Federal Senate: Graphic Center, 1988.

BRAZIL. Law No. 10,257 of July 10, 2001. City Statutes and Related Legislation. 2nd ed., Current. Brasília: Federal Senate, Subsecretaria de Edições Técnicas, 80 p., 2002.

CPRM - Geological Survey of Brazil - Aquifers. Available in: http://www.cprm.gov.br/publique/cgi/cgilua.exe/sys/ start.htm?infoid=1377\&sid=129. Acessed 14/12/2017.

CORMIER, N. S., \& PELLEGRINO, P. R. M. Green Infrastructure: A Landscape Strategy for Urban Water, Landscape Environment: Essays n.25 / São Paulo, p. 125-142, 2008.

DE OLIVEIRA, E. M., SOARES, M. C., BONZI, R. S. Application of the environmental design for the owl stream watershed: Potentials and limitations in the implementation of a linear park. LABVERDE Magazine, n. 4, p. 31-62, 2012.

FINDLAY, S. J., TAYLOR, M. P. Why rehabilitate urban river systems ?. Area, v. 38, n. 3, p. 312-325, 2006.

FORMAN, R. T. Land Mosaics: The Ecology of Landscapes and Regions. Island Press, 1995.

JAGUARE PROJECT. Development of a methodology and pilot project to revitalize the urban watershed, replicable for the other watersheds in the metropolitan region (Jaguaré Watershed) 2014 AT-653, FCTH, 2017.

PELLEGRINO, P.R. M., MOURA, N.C. B. de. Strategies for a green infrastructure. Barueri: Manole, 2017.

POLETO, C. SUDS (Sustainable Urban Drainage Systems): A Historical Context. Revista Thema, v. 8, n. 1, 2011.

SAO PAULO. Law 13,276, dated January 4, 2002. It makes the execution of a reservoir mandatory for waters collected by roofs and floors in batches, whether or not built, with a waterproofed area greater than $500 \mathrm{~m}^{2}$. Available at http://www.al.sp.gov.br/repositorio/legislacao/lei/2007/lei-12526-02.01.2007.html. Accessed on: Dec, 2017. 
MELO, T. dos A., COUTINHO, A. P., CABRAL, J. J. S. P., ANTONINO, A. C. D., CIRILO, J. A. Rain garden: bioremediation system for urban storm water management. Built Environment, Porto Alegre, v. 14, n. 4, p. 147-165, Oct./Dec. 2014.

FCTH, Foundation Technological Center of Hydraulics. Technical project: rain gardens. Available at: http://solucoesparacidades.com.br/. Accessed on: Dec, 2017.

SÃO PAULO, Law No. 15,733, May 3, 2013. It introduces changes to Law No. 15.442, of September 9, 2011, as well as rendering non-effect fines, as specified. Available at: http://www3.prefeitura.sp.gov.br/cadlem/secretarias/negocios _juridicos/cadlem/integra.asp?alt=04052013L\%20157330000. Accessed on: Dec, 2017.

SILVA, J. C. A.. Urbanized watersheds: restoration, revitalization, and recovery. A study of the Jaguaré watershed. 2017. Thesis (Doctorate in Hydraulic Engineering) Polytechnic School, University of São Paulo, São Paulo, 2017. doi:10.11606/T.3.2017.tde-01092017-150153.

TOMAZ, P. Rainwater management course, Rational method. Chapter 2, São Paulo SP, 2013.

TOMAZ, P. Removal of sediments in BMPs. Guarulhos: Portal Plinio Tomaz, 2008. Available at: http://pliniotomaz.com.br/livros-digitais/. Accessed on: Dec, 2017. 278p.

UACDC - LID, Low Impact Development a manual design for urban areas. UACDC, Fayetteville, Arkansas, 2010. Available at: http://uacdc.uark.edu. Accessed on: Dec, 2017. 